\title{
TREND ANALYSIS OF CAR RECALLS: EVIDENCE FROM THE US MARKET
}

\author{
Kamrul Ahsan \\ College of Business, Victoria University, \\ 300 Flinders Street, Melbourne 3000, Australia
}

\begin{abstract}
Influenced by Toyota's recent automobile recalls 2009-2010, and highlighting the importance of recalls research, this study conducts a car recalls trend analysis for the US market that is a first of its kind. The research uses secondary data from recall websites maintained by public and private organizations. The study shows recalls are a common event with the majority of recalls initiated by only a few carmakers. Though carmakers use many eye catching and popular quality and customer care slogans and programs, many popular car makers still face valid customer complaints and consequently face many unwanted recalls. Results of automobile recall trends analysis will be beneficial for car makers, government authorities who deal with recalls, insurance companies, and researchers.
\end{abstract}

\section{KEYWORDS}

Automotive recalls, product recalls, reverse logistics, closed loop supply chain

\section{INTRODUCTION}

Though manufacturers use state-of-the-art operations philosophies, tools and techniques, it is difficult to make the perfect product and products often need to be recalled[1]. Recalls are a consequence of non-conformance to qualitystandard or specificationor due to health and safety risk to use the products, which the manufacturer did not address or was unaware of before distribution and sales in the market[2,3].Recent recalls of numerous products in multiple industries suggest that firms are not immune to product recalls [4]. A good example is Toyota's large number of car recalls in 2009 and 2010 due to floor mat and sudden acceleration problems, resulting in high recall costs to Toyota and its supply chain members and stakeholders. This recall not only incurred huge litigation fees, but also resulted in estimated losses in the billions of dollars of lost sales[5].

Recalls are a part of reverse logistics where recalled products, information, and cash flow are in the opposite direction of the normal supply chain. Recall operations are mostly service oriented and often as difficult as the forward supply chain. Usually, the manufacturer needs to organize and support logistics, and technical, financial, and legal issues related to recalled products[6]. The process of product recall is cumbersome. Members of the entire supply chain are directly or indirectly affected by recalls. It is a complex process to track affected customers and locations.A quick response to customer complaints and quick resolution of the problem is vital.Mishandling or late handling of recalls can seriously affect customer goodwill related to certain products or brands or manufacturers and that consequently can erode company profit to a large extent. A good example of lengthy recall process includes the Ford Motor and Firestone Tyre recall 2000, that took more than seven years from the first report until a final decision was reached[7]. The recent increase in product recall has shifted attention from why products are recalled to why it takes so long to recall a defective product that poses a safety hazard [4]. Companies are still not prepared to deal with recalls nor do they recognize how great an impactrecalls can have on an 
organization's reputation. The point is that risks are higher than ever for the companythat fails to anticipate the possibility of a product recall[8].

The cost of recalls is enormous for all parties in the chain. Product recalls due to safety hazards entail social costs, such as property damage, injury, and sometimes death [4]. Costs of product recall through the reverse distribution channel are at least two or three times higher than costs incurred in forward distribution, often due to small quantities of shipments, fluctuating and uncertain demand, and the urgency involved in the recall process [9, 10].Costs to customers sometimes amount to death or physical disability. For the manufacturer, costs are quite substantial and can be compared with the cost of quality.The cost function can be the cost of recall operations, cost of product replacement or repair, cost of losing market share or goodwill, cost of marketing the brand value, cost of lawsuit settlements, and cost of closing share price [11, 12].

There are various categories of recalled products and these include: automobiles, children's products, appliances, computers and accessories, furniture, sports and recreation products, perishable items, food items, medicine etc. Among remarkable toy recalls, Mattel's recalls due to lead-paint hazards for children in 2007, and Mattel/Fisher Price recalls in 2010 have made news. About 11 million tricycles, toys and high chairs were recalled due to safety hazards. Furthermore, 100,000 toys were also recalled due to choking hazard [13]. Recalls for food products are also very common. Some high profile safety incidents are 'mad cow disease in the UK' during 19861987, 'salmonella outbreak in peanut butter paste in the US and Canada' during 2008-2009, 'melamine in infant's formula produced by Chinese company San-lu[13].Among recalled products, car recalls are very common and often make international news. Most recently, the automobile industry has received a great deal of attention in recall literature due to a series of large recalls by Toyota and other leading manufacturers.

Car safety recalls are by definition significant events: they are carried out in the name of protecting drivers, passengers and the general public, but for general manufacturers and component suppliers the process can be expensive and adversely impact brand value [14]. Some historical car recalls include Toyota faulty pedals and floor mats in 2010, Ford cruise control in 2009, Firestone tires in 2000, Ford Pintos in 1978 etc. These recalls made headlines because of their impact on stakeholders. A safety recall occurs when vehicle manufacturers call vehicles that have been sold and are in use back to their dealerships for safety-related remedial work [14]. In the US, Automotive manufacturers are required to conduct a recall due to safety-related defects for vehicles up to eight years old [15]. Usually, customers present car related problems to the dealer or manufacturer for a solution. The process may be time consuming and the complaint may end as a lawsuit with the respective government authority dealing with the manufacturer to come to a compensation settlement for customers.

Though car recalls are large in volume and is frequently occurring, research in the area of recall operations is not plenty like other areas of reverse logistics. For the US market recall trends research is rare:Barber and Darrough [16], and Nichols and Fournier [17] compare the evolving reputations of American and Japanese manufacturers, while Rupp and Taylor [18] and Rupp [15] study causes and effects of the most costly automobile recalls during the period up to 1998. Realizing the importance of recall research this study makes an attempt to provide an insight of car recalls trends and relevant information. This study focuses on historic car recall data for the US. For different car model year and manufacturer: customer complaints, frequency of recalls and yearly sales data are analyzed.For each category, particular focus is given on Toyota to investigate this leading carmaker's situation, and trends and issues regarding the recalls. Overall, the main research objective is to analyze whether recalls are a discrete event. This study answers the following questions: Are there any significant differences in recall frequencies 
between different car manufacturers? Are there any significant relations in recall frequencies between different car model years? Are there any significant relations in recall frequencies between customer complaints? Which car makers have more customer complaints related to product quality and safety?

The paper is organized as follows: in section two, literature review of the car recall process and previous relevant research is discussed; in section 3 , the research methodology and data collection process is described; followed by analysis and discussion in section 4; finally research summary and future research directions are highlighted in the conclusion.

\section{EXPLORATION OF RECALL LITERATURE}

Recalls are important to the customer, manufacturer, distributor, government, and other inter related supply chain parties. Recent recalls of numerous products in multiple industries suggest that firms are not immune to product recalls [4]. Realizing the importance of recalls within the product supply chain a detailed review of recalls literature is compiled with a particular emphasis on car recalls.

\section{1 Recalls Process}

Product recall is a reverse distribution activity that withdraws goods from customers. A product recall seeks to withdraw the product from the market as it was sold. The products are either hazardous or defective or are not according to the specification or do not comply with government compliances. The recall process typically entails an official announcement (recall notice) outlining the reason for the recall and a remedy offered to the customer [4]. If customers encounter problems, they inform the retailer or local supplier. When many customers encounter the same problem, manufacturers (or sometimes a government authority) investigate the issue, take a recall decision and inform respective customers and stakeholders. If manufacturers do not recall or do not respond to customer complaints, then the government authority investigates further. If government experts find a safety standard violated, they contact the manufacturer, who starts the recall process. On rare occasions, manufacturers fight the decision of the government and bring the issue to court.Once recalls are announced, manufacturers send letters to customers and announce the recall through the media so that the product can be brought in and the issue resolved.

Car recall notices are usually archived by government, semi-government or private organizations. For example, in the U.S., consumer product recall information is archived by the Consumer Product Safety Commission-CPSC, and car recalls are initiated by the National Highway Traffic Safety Administration [19].These organizations maintain websites to provide up-to-date product recall information for all stakeholders, and information is available to the public.In the case of car recalls in the US, NHTSA deals on behalf of the US government, and other countries have similar authority to handle recalls.Organizations like Automotive Recalls for Consumers [20] and myCarsStats use NHTSA data and update recall data in more user friendly form.

After careful investigation of several historical car recalls, this research identifies and shows a generic recalls process in Figure 1. The whole process of recall is lengthy. For example, the Firestone tire recall that affected Ford vehicles took more than seven years from the first report until a final decision was reached. There are many steps before a final decision to recall vehicles is made [21].Usually it is very hard to track customers hand their locations; in this case mass media is used to spread news to customers. Sometimes manufacturers take time to respond to customer complaints and in some case it goes to court in the form of a lawsuit and the respective government authority deals with the manufacturer to come to a settlement compensation for 
customers. Good examples include the Ford Motor and Firestone Tyre recall 2000, and 8.5 million car recalls of Toyota during 2009-2010. In case of Ford, the NHTSA received letters from Explorer owners in the USA since the early 1990. In July 1998, the NHTSA received data from insurance company regarding 21 cases of Firestone tyres for Ford Explorer accidents. After receiving more complaints the NHTSA announced a formal defect investigation into 47 million TAX, ATXII and Wilderness tyres manufactured by Firestone [7]. In the case of Toyota, US customers made complaints to the NHTSA regarding power steering, breaks, and floor mats. Toyota and the government looked into complaints, and it was later resolved through congress hearing.

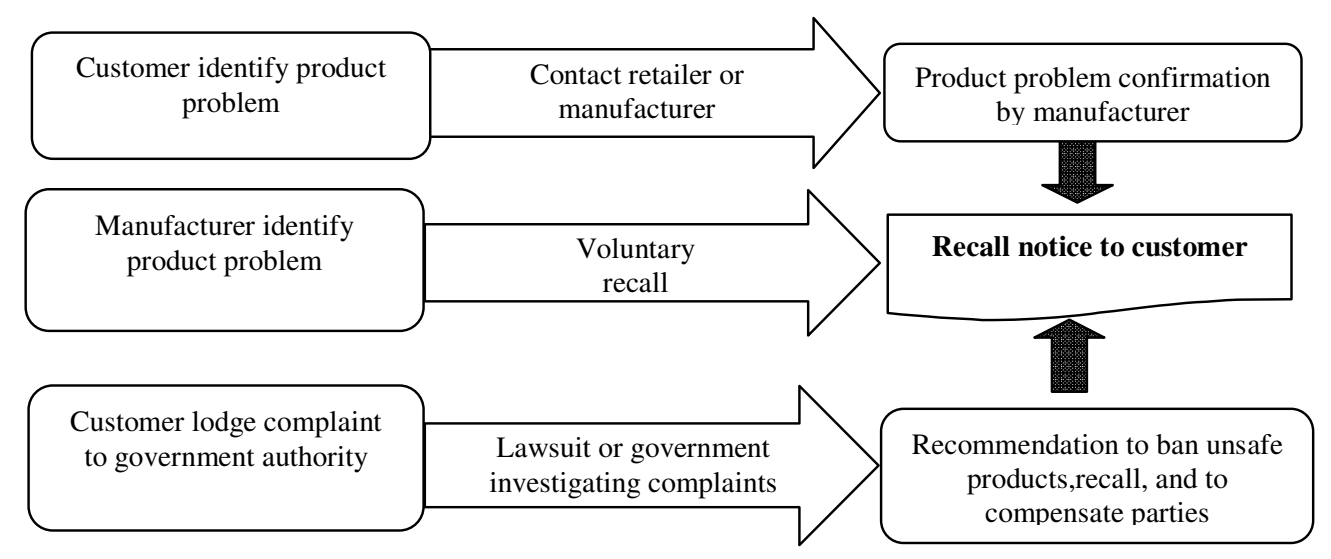

Figure 1. A generic car recall process

\subsection{TYPES OF RECALLS}

Recalls are classified as either voluntary/proactive or involuntary/reactive. Research shows that preventive recall strategy takes a longer time to recall compared to reactive recall strategy [4]. Voluntary recalls are initiated by proactive manufacturers who suspect a defect or have some concern regarding product quality and reliability. For example in the auto industry, recalls are considered manufacturer-initiated or voluntary if NHTSA has not opened a defect safety investigation prior to the company's decision to conduct recall [18]. Involuntary or reactive recalls are forced; due to non-compliance issues or when multiple customer complaints regarding some product, or a government agency enforces a company to initiate a recall. For example, in case of car recalls in the US market, government recalls follow a series of investigation stages. The NHTSA collects data from written, telephone, or electronic submission of consumer complaints [15]. Every complaint is forwarded to the manufacturers. If the NHTSA receives enough complaints about a particular defective component, they go through a comprehensive investigation process and based on the investigation outcome they ask manufacturers whether it is necessary to conduct a safety recall or not.

With respect to severity and impact on customers, recalls can also be classified as class I, II and III [22]. Class I is the most severe, in this category the use of, or exposure to the product will cause serious, lasting adverse health problems or death. Class II types of recall may cause temporary health consequences. Lastly, class III, is the least serious type of recall, and generally does not involve any adverse health consequences. 


\subsection{RECALLS VOLUME AND IMPACTS}

Most of the recalls are related to product safety and security and are from five major industries such as food, pharmaceuticals, medical devices, consumer products and automobiles [13].Product recalls are increasing in frequency and volume. In 1988, the U.S. Consumer Product Safety Commission was involved in some 221 recalls frequencies covering about 8 million product units. Five years later in 1993, those numbers had risen to 367 recalls covering about 28 million product units.

In the case of automobiles in 1966, 58 recalls were issued. In 2000, the number of recalls issued had increased to 631, and by 2008 they were close to 800 . The total number of recalls from 1988 to 2001 was 5,233 . The average potential number of units affected was 94,237 . The number of units that are issued to each recall range from 1 to 32 million [21]. The number of automobile recalls in the U.S. has increased sharply in the last two decades, and the numbers of units involved are often counted in the millions. In 2010 alone, over 20 million vehicles were recalled in the United States[21].

Recalls for both new and established products occur all too often, and they can have serious consequences. Product recalls due to lack of safety highlight quality failures that can be expensive for companies. Consumers react negatively to recalls unless the recalling company acts proactively and in a socially responsive manner [4]. The magnitude of a recall's negative impact on company performance varies by recall severity, firm size, and remedy to recall [23-25]. Research finding the link between automakers reputation with recalls shows that firms with a stronger reputation experience a higher reduction in their market value than do firms with a weaker reputation [26].

\subsection{PRODUCT RECALLS RESEARCH}

We classify previous research on product recalls into these categories: characteristics of recalls (recall trends, reasons of recalls), customer related issues of recalls (safety and service), product issues (defects and repair), impact of recalls (sales, profit, share market), and recall operations (planning for recall, process, recall initiator, assured customer service). Under each category, some of the research and their main focus are shown in Table 1.

Table 1: Product recall research areas

\begin{tabular}{|c|c|c|}
\hline $\begin{array}{l}\text { Recall } \\
\text { research areas }\end{array}$ & Research focus & $\begin{array}{l}\text { Research method/Data } \\
\text { source }\end{array}$ \\
\hline \multirow[t]{3}{*}{$\begin{array}{l}\text { Characteristics } \\
\text { of recalls }\end{array}$} & $\begin{array}{l}\text { Bates at el. [14] identify that car recall rates are } \\
\text { increasing. Research also shows that there are } \\
\text { substantial differences in recall rates between } \\
\text { different car manufacturers; European and } \\
\text { American producers have nearly three times } \\
\text { greater recalls rates than their East Asian } \\
\text { counterparts. }\end{array}$ & $\begin{array}{l}\text { Based on } 23.1 \text { million } \\
\text { vehicles registered data } \\
\text { in the UK between } 1992 \\
\text { and } 2002\end{array}$ \\
\hline & $\begin{array}{l}\text { Characteristics of US meat and poultry recalls } \\
\text { during } 1994-2002 \text { are studied by Teratanavat and } \\
\text { Hooker (2004). Authors identify the reasons for } \\
\text { meat and poultry recalls, and how recall } \\
\text { problems were identified. }\end{array}$ & $\begin{array}{l}\text { Food Safety and } \\
\text { Inspection Service } \\
\text { (FSIS) recall data from } \\
\text { 1994-2002 were used. }\end{array}$ \\
\hline & $\begin{array}{l}\text { Lyles, Flynn and Frohlich [3]conceptualize and } \\
\text { highlight the product recall issues from the }\end{array}$ & $\begin{array}{l}\text { Conceptual paper on } \\
\text { issues in China's }\end{array}$ \\
\hline
\end{tabular}


International Journal of Managing Value and Supply Chains (IJMVSC) Vol.4, No. 4, December 2013

\begin{tabular}{|c|c|c|}
\hline & perspective of the supply chain. & product recall \\
\hline & Types of recall and organisational learning [27] & $\begin{array}{lr}\text { Major data } & \text { source: } \\
\text { NHTSA, } & \text { Wards } \\
\text { Automotive Yearbook }\end{array}$ \\
\hline \multirow[t]{2}{*}{ Customer issues } & $\begin{array}{l}\text { Choi and Lin[28]analyse consumer response to } \\
\text { crisis and safety in regards to the } 2007 \text { Mattel } \\
\text { product recalls and how mass media covered the } \\
\text { same recall. }\end{array}$ & $\begin{array}{l}\text { Content analysis of } \\
\text { online bulletin board } \\
\text { and newspaper articles }\end{array}$ \\
\hline & $\begin{array}{l}\text { Bae and Silva [21]quantify the effect of vehicle } \\
\text { recalls on safety. Recalls classified as hazardous } \\
\text { are more effective in reducing accidents. }\end{array}$ & $\begin{array}{l}\text { Empirical research } \\
\text { based on NHSTAdata }\end{array}$ \\
\hline \multirow[t]{2}{*}{ Impact of recall } & $\begin{array}{l}\text { Rupp [15]investigates impact on stock market } \\
\text { returns to both manufacturer and government } \\
\text { initiated recall. }\end{array}$ & $\begin{array}{lr}\text { Empirical } & \text { research } \\
\text { based on Wall Street } \\
\text { Journal }\end{array}$ \\
\hline & $\begin{array}{l}\text { Jarrel and Peltzman[29] estimate the losses borne } \\
\text { by owners of a firm that recall a defective } \\
\text { product. For car recall, they analyse stock market } \\
\text { response to the news of product defects. }\end{array}$ & $\begin{array}{l}\text { Wall Street Journal } \\
\text { Automobile recall data }\end{array}$ \\
\hline \multirow[t]{4}{*}{$\begin{array}{l}\text { Recall } \\
\text { operations }\end{array}$} & $\begin{array}{l}\text { Effectiveness and efficiency of recall process has } \\
\text { been studied by Eagle, Rose, Kitchen and } \\
\text { Hawkins[30]. The basis of the study is } \\
\text { Government enforced withdrawal of around } \\
2000 \text { medicine products from Australia and New } \\
\text { Zealand. Authors suggest a product recalls } \\
\text { system and consumer relation's initiatives. }\end{array}$ & $\begin{array}{l}\text { Research is based on } \\
\text { media coverage and } \\
\text { interviews (with } \\
\text { manufacturers, retailers, } \\
\text { and regulatory bodies). }\end{array}$ \\
\hline & $\begin{array}{l}\text { The recall initiator (either the government or the } \\
\text { manufacturer) does not serve as a reliable signal } \\
\text { of product quality and investors should not make } \\
\text { equity on the basis of who initiated the safety } \\
\text { recall [15]. }\end{array}$ & $\begin{array}{l}\text { Empirical: Used Wall } \\
\text { Street Journal 1973- } \\
1998 \text { US automotive } \\
\text { safety recall data for the } \\
\text { six largest producers of } \\
\text { cars and tracks }\end{array}$ \\
\hline & $\begin{array}{l}\text { Berman [11] emphasises importance of planning } \\
\text { for a product recall (car recalls) through proper } \\
\text { readiness, implementing safety inspection } \\
\text { process, updating customer database, and } \\
\text { considering recall activities from relationship } \\
\text { marketing perspective. }\end{array}$ & Conceptual paper \\
\hline & $\begin{array}{l}\text { Kumar and Budin }[22] \text { suggest potential } \\
\text { reduction of product recalls through preventive } \\
\text { measures and proper management of recalls in } \\
\text { the process food industry. }\end{array}$ & $\begin{array}{l}\text { Interviews with } \\
\text { international quality } \\
\text { experts }\end{array}$ \\
\hline
\end{tabular}

Analysis of previous research on recalls show that most of the research was based on secondary data and empirical research, and less research has been conducted in the areas of identifying the trends of car recalls in the US market.

\subsection{CAR RECALLS}

Due to recalls end customers suffer; and business faces criticism, and law-suits, lose customer goodwill and count financial losses. Recalls are the result of product related problems and issues 
and a sign of bad quality product. Historically, the operations management discipline was concerned with the issues related to quality in product development and manufacturing. Many popular philosophies and tools (such as SPC, TQM, Six Sigma) have been developed and companies are widely adopting zero defect strategies. However, in reality the picture is different; every year car manufacturers are conducting many recalls that cost a lot to customers as well as other supply chain members. Though during the 90's a research [16] identifies Japanese manufacturers to have fewer recalls than their US counterparts, recent recalls question the conclusion and further research is necessary to identify the current trends in the market.

Toyota has been the quality and reliability benchmark in the manufacturing world; however because of the recent huge number of car recalls, people are questioning what went wrong with mighty Toyota! Toyota's 8.5 million car recall during 2009-2010 due to sudden acceleration and floor mat problems can be considered a high profile recall in terms of media coverage, number of recalled cars and estimated losses. On November 2009, Toyota recalled 4.2 million cars in the US due to floor mats that could trap accelerator pedals. On January 21, 2010, Toyota recalled 2.3 million cars in the US due to sticking accelerator pedals. Afterwards on January 28, afterwards 1.1 million cars were recalled due to floor mat problems. On February 9, 2010 the Toyota Motor Corporation (TMC) president Akio Toyoda official apologized announcement is as follows (http://www2.toyota.co.jp/en/news/10/02/0209.html):

"Let me assure everyone that we will redouble our commitment to quality as the lifeline of our company. With myself taking the lead, all of us at Toyota will tackle the issue in close cooperation with our dealers and with our suppliers. Together, we will do everything in our power to regain the confidence of our customers,"

These series of recalls created problems for Toyota's profit, share price, and reputation. Toyota had to pay about US\$7 billion in litigation fees, and estimated losses were in the billions due to lost sales, reduced manufacturing output, and enhanced incentive campaigns [13]. Now questions arise for further investigation: is Toyota losing its shine? Is this unique to Toyota or any other particular carmaker?

Car recall studies in the literature are scarce although in the last decade recalls research has increased. Based on the famous Ford Motor and Firestone tyre recalls a case study was conducted by Moll [7], the case addresses potential causes of the recall and how Ford handled the crisis. Recalls related organizational learning has been studied by [27], the study finds that voluntary recalls result in more learning than mandated recalls when learning is measured as a reduction in subsequent involuntary recalls. Based on stock market reaction to recalls, Rupp [15] identifies that recall initiator (either the government or the manufacturer) does not serve as a reliable signal of product quality and investors should not make equity on the basis of who initiated the safety recall. Bae and Benítez Silva $[14,21]$ quantify the effect of vehicle recalls on safety, and investigate vehicle recall and its relation with the reduction of number of accidents: recalls classified as hazardous are more effective in reducing accidents. Recently, in an editorial essay Marucheck et al. [13] address product safety and security issues regarding five high profile product categories including car recalls; the essay identifies four areas related to recalls (regulations and standards, product lifecycle management, traceability and recall management, and supplier relationships) where operations management theories and methods can assist further. Bates et al. [14]is the only research found in the literature related to automobile recall trend analysis. Based on 23.1 million vehicles registered in the UK between 1992 and 2002, the Bates et al. [14]investigate patterns and trends in motor vehicle safety recalls in the United Kingdom. The study identifies car recalls are increasing between 1998-2002, and there is was an average 120 recall incidents per annum compared to 50 per year during 1992-1994. Research shows that there are substantial differences in recall rates between different car manufacturers. European and 
American producers have nearly three times greater recalls rates than their East Asian counterparts. This research was conducted based on the UK car industry. However, a similar research for the US could be of great interest for car recall research. The US car industry is the world's largest, most world class manufacturers are located in the US, and the number of recalls and number of recalled vehicles are huge. For example in 2009 in the US market alone 16.4 million vehicles were recalled, and in 2010 more than 20 million were recalled (Source: NHTSA; [21]).

Identifiying the research gap and the importance of recall research in the US, this research conducts a car recalls trend analysis for the US market. This research investigates the frequency of car recalls as the dependent variable; and car model, car manufacturer, and customer complaint as independent variables. This research answers which car makers conduct the most recalls, and analyzes the recall frequency correlation with other prescribed variables.

\section{METHODOLOGY AND DATA COLLECTION}

This research is based on secondary data from car recall notices archived by NHTSA. Research based on secondary data offers great opportunities for new studies in operations and supply chain management ([31][32][33][34]). There are several advantages to using this data for research into car recalls. Primarily, because of the authenticity of the information, and also since data is widely available from a source and less expensive. Furthermore, data sourced from archives is more objective than primary survey data as it is free from contamination by respondent perceptions and memories of the phenomenon of interest [35]. On the other hand, of the major limitations data from computers or reports are not always accurate, and results depend on quality and comprehensiveness of project reports. Many data (e.g., financial reports) are quite noisy, making statistical significance of hypothesized relationships hard to establish [31]. Considering the above benefits and limitations this study considers car recall archival data as a good source for credible research.

This study is based on US car recall related data from January 2000 to April 2010. Data in the form of car recall numbers, customer complaints, and car sales were taken from several authenticated sources. Recall frequency is considered a measure of recall, as it represents the number of recall notices made to the public. Customer complaints for a particular car model refer to the number of written complaints about a particular problem. Customer complaints are considered a cause of recall. Car sales data is used to estimate market share and popularity of the car maker and model. Stock market closing share price data is collected to examine the situation of a company before, during and after the recall. The impacts of recall on stakeholders are associated with share price and sales data.

Car recall and customer complaint data are collected from websites such as National Highway Traffic Safety Administration, USA [19], Automotive Recalls for Consumers [20], my car statistics [36]. Car sales data was retrieved from Reuters, Ward's AutoInfoBank, and Toyota [3739]. NHTSA allows the public to file complaints about vehicles; complaints can be submitted by phone, fax, mail or online and are typically reported by consumers and attorneys (NHTSA website). The complaints are monitored by NHTSA's Office of Defects Investigation, which looks for trends and, in some cases, orders investigations.

US car recall related information is available from the NHTSA database.Complaints on file come directly from consumers who have registered their problem with the United States Department of Transportation. These registered consumer complaints often are a good indication if this model of car has a history of problems that may not show up as recalls or technical service bulletins. But 
these car complaints are still a concern to the owner especially when they are substantiated by different consumers reporting the same problem.

NHTSA is responsible for investigating possible automotive design and manufacturing defects. When consumers file a complaint to NHTSA, and after several complaints are filed regarding the same mechanical or safety related problem, NHTSA will often investigate the issue to determine whether the consumer or the manufacturer is at fault. If the manufacturer is at fault a recall may be issued to rectify the problem [36].

\section{DATA ANALYSIS AND DISCUSSION}

This research investigates recalls through different control variable such as car maker, model year, customer complaints and sales. Initially, the research categorizes the most popular cars makers with regards to market share data. In the latter stage, frequencies of recalls are analyzed with respect to the above variables.

Using historical car sales data for the last decade, the study identifies the most popular cars. According to sales data, in the US the most popular car makers are GM, Ford, Toyota, Chrysler, Honda, and Nissan. Considering sales under recent (2005-2010)and past (2000-2004) categories, it can be seen from Figure 2 that in the past Toyota's position was below the Detroit Big three manufacturers. However, since 2005 Toyota's position has improved in terms of market share and it remained so until the end of 2009. At the end of 2009, Toyota was the number 2 car maker in the US.However, sales declined for Toyota from the end of 2009 to the beginning of 2010. From March 2010 Toyota started regaining it's share slowly. Considering differences between past and recent market share, it is reasonably clear that the US giant car manufacturers are not doing well in comparison with Japanese makers (Toyota, Honda and Nissan).Furthermore, considering differences between highest and lowest market share data (High-Low sales), it is remarkable that the recent market is more competitive, market share is very close among competitors, and in this competitive market Japanese makers are doing well.

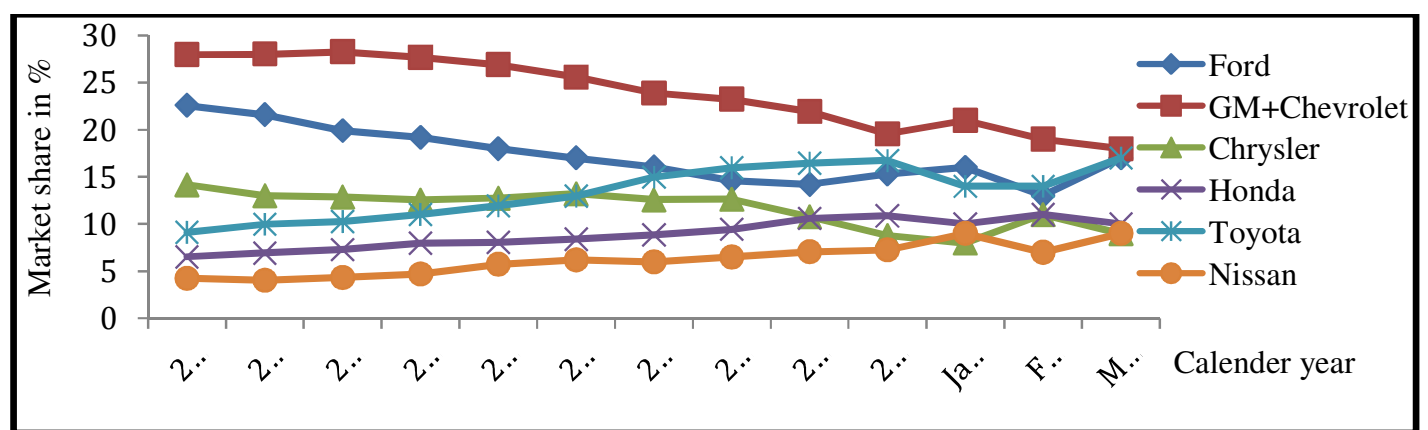

Figure 2.Popular US and Japanese cars in the US market

\subsection{FACTORS AFFECTING THE NUMBER OF RECALLS}

\section{(i) Recalls and Car Makers}

From historical data (2000-2010) this study analyses recalls frequency among car manufacturers. Every car maker conducts recalls; the average number of recalls is 3.5 per month. It can be seen from Figure 3 that the majority of recalls are initiated by only a few car makers. According to the number of recalls, the top six manufacturers are Ford, GM\&Chevrolet, Honda, Toyota, Nissan and Chrysler. These makers have conducted about $70 \%$ of total recalls during the last ten years. 
On average, Ford has conducted about 4 recalls per week, and Toyota and Nissan have conducted one recall per week. Details of recalls and makers information can be seen from Figure 3, where car makers recall frequency is shown in average number of recalls per month. Among the makers, Toyota's is in 3rd position in terms of total recall frequency.Considering the top six car makers recall data, we consider that the average numbers of recalls are the same for all six manufacturers. Oneway ANOVA analysis shows there exist no sigificant differences in the recall frequency of the major car makers.

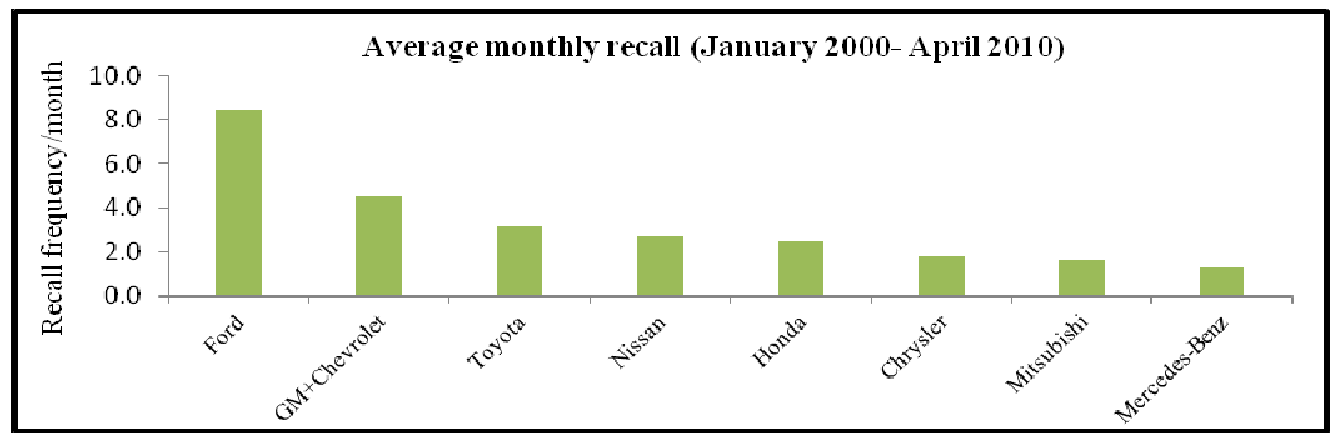

Figure 3.Car makers and recalls frequency : 2000-2010

\section{[40]Recalls and Car Models}

Comparing the recall frequency of the top six car makers for the 2000-2010 models, it is noticeable that older models have more recalls compared to the more recent models (Figure 4). Perhaps, it takes time to identify car's problems for recalls. Furthermore, Japanese cars have had the most recent recalls amongst their counterparts, and among the Japanese cars Toyota's number of recalls have increased recently (October 2009 and January 2010).

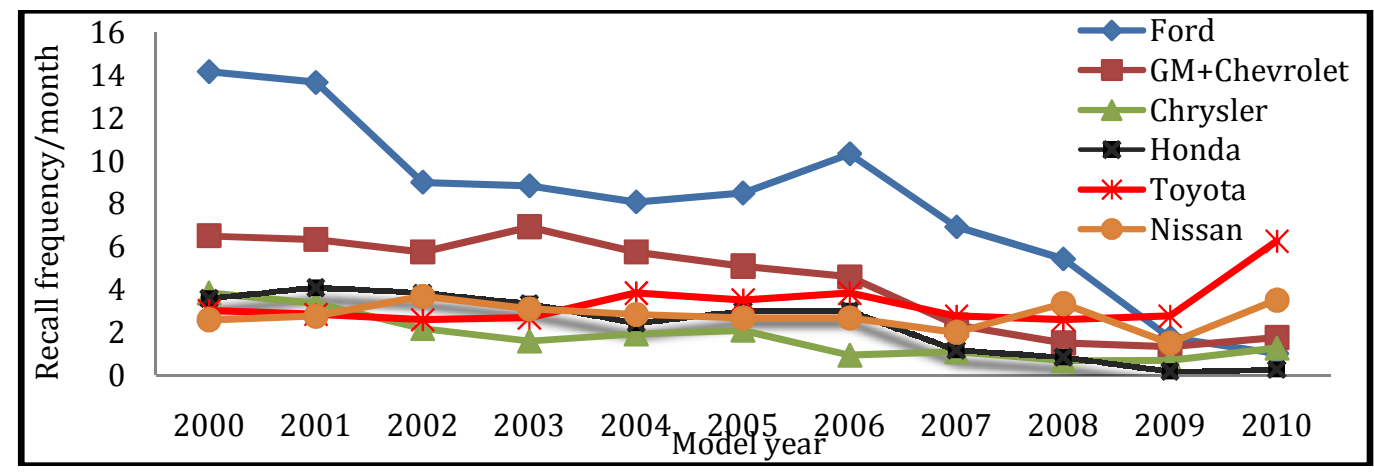

Figure 4. Recalls frequency and car model years

Furthermore, this research considers that the average numbers of recalls are the same for different car model years. One-way ANOVA analysis shows differences in car recall frequencies among different models ( $p$ value is less than 0.001) and model year accounts for $53.2 \%$ of the total variation in recall frequency. Pearson's correlation analysis shows that there exists a significant negative correlation between the car model year and recall frequency (correlation 0.711, significant at the 0.01 level). Which means, olders models have more recalls than new models. 


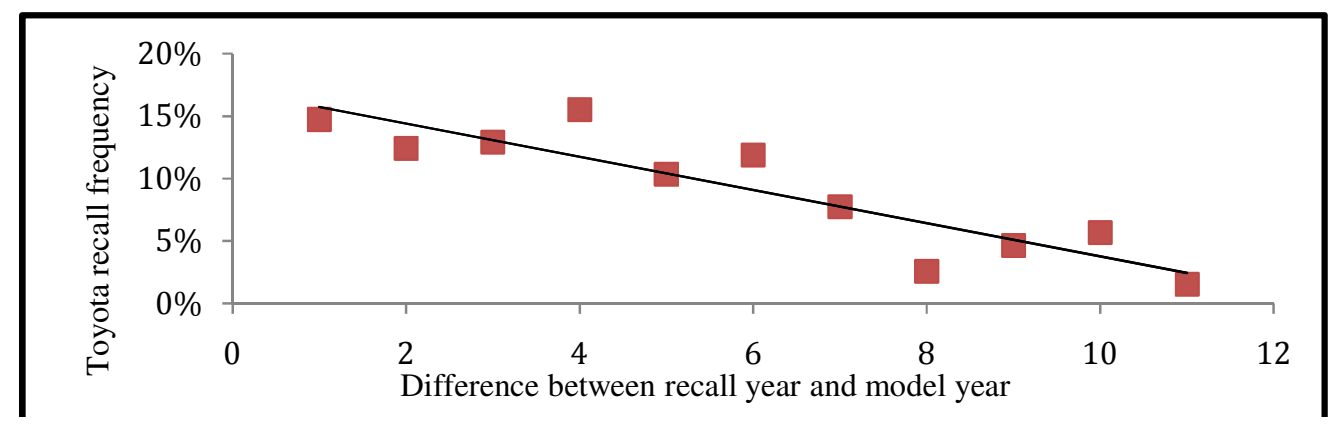

Figure 5. Recalls relations with car recall year and model year

Considering only Toyota's historical recalls, this research investigates which year of the car life has more recalls. Behaviour of recall frequency ratio (number of recalls for a model/total number of recalls for all the models) is compared with the recall time after the model year (i.e. recall year minus car model year). From statistical analysis, it can be seen that there exists a strong negative correlation between the two variables (Pearson's correlation -0.886) and the correlation is significant at 0.001 level. It can be seen that most of the recalls happen during the first five years of a model year (Figure 5).

\section{[40]Recalls and Customer Complaints}

From historical recall data it can seen that popular car makers have more customer complaints. Ford, GM and Toyota are the top three manufacturers in terms of more complaints with the NHTSA regulations and details can be seen from Table 2. Ford has the greatest number of recalls and the highest number of customer complaints. From 2000-2010, based on NHTSA data, Ford had 39,462 complaints, compared with Toyota's 25,412. Historically, we know that many customer complaints trigger car recalls. It will be interesting to know further whether customer complaints trigger recall notices or if there is any relationship between recall frequency and customer complaint. This research considers that recall numbers are the same for any number of complaints. Statistical analysis (one-way ANOVA) shows that the relationship between recall frequencies and customer complaints is statistically significant at $5 \%$ ( $p$ value $=0.003$ ). It can be concluded that the higher the number of customer complaints the more the recalls (from Figure $6)$.

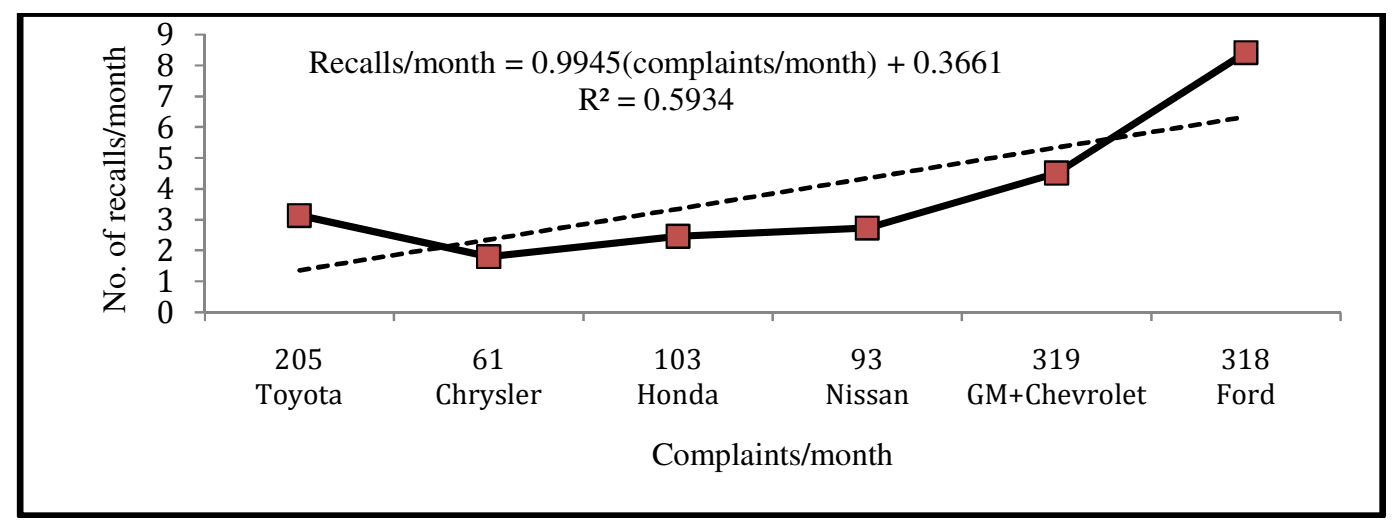

Figure 6. Relationship between recalls and customer complaints

Based on historical data, a summary of comparative ranks of the top car makers are shown in Table 2. It can be seen that Ford and GM are two pioneers in terms of positive (sales) and 
International Journal of Managing Value and Supply Chains (IJMVSC) Vol.4, No. 4, December 2013

negative (recall number, customer complaints) aspects. Whereas, Toyota's position is in the middle in terms of popularity and recalls.

Table 2: Overall position of car makers (January 2000-March 2010)

\begin{tabular}{|l|ll|ll|ll|}
\hline \multirow{2}{*}{$\begin{array}{c}\text { Car } \\
\text { manufacturer }\end{array}$} & \multicolumn{6}{c|}{ Rank order criteria } \\
\cline { 2 - 7 } & $\begin{array}{l}\text { Average } \\
\text { yearly market } \\
\text { share }\end{array}$ & Rank & $\begin{array}{l}\text { Total recall } \\
\text { number }\end{array}$ & Rank & $\begin{array}{l}\text { Total no. of } \\
\text { customer } \\
\text { complaints }\end{array}$ & Rank \\
\hline Ford & 23.33 & 2 & 1044 & 1 & 39462 & 2 \\
\hline GM \& Chevrolet & 31.95 & 1 & 560 & 2 & 39520 & 1 \\
\hline Chrysler & 15.61 & 4 & 224 & 6 & 7586 & 6 \\
\hline Honda & 12.37 & 5 & 306 & 5 & 12754 & 4 \\
\hline Toyota & 18.42 & 3 & 389 & 3 & 25412 & 3 \\
\hline Nissan & 8.52 & 6 & 339 & 4 & 11534 & 5 \\
\hline
\end{tabular}

\subsection{RECALLS, CUSTOMER COMPLAINTS AND CAR MODEL YEAR}

Comparing car model year and average number of customer complaints, from Figure 7 it can be seen that except Toyota, for other car makers the numbers of complaints were higher for the older models and lower for the latest car models.Comparing the total number of customer complaints, during the last decade Toyota's position is at number three. For Toyota, on average 3 customer complaints were recorded per month per model year; Toyota has $9 \%$ of total recorded customer complaints with a standard deviation of $2.28 \%$.Among all cars, recent Toyota models have a higher number of customer complaints than rival makers. On the other hand, Ford has a history of a high number of customer complaints for 2000-2003 model cars. Amongst all the cars there exists a strong negative correlation between car model year and customer complaints, and the correlation is significant at the 0.01 significance level. It can also be seen that popular car makers are experiencing more customer complaints. Analysis shows that among top manufacturers differences in number of customer complaints are not significant.

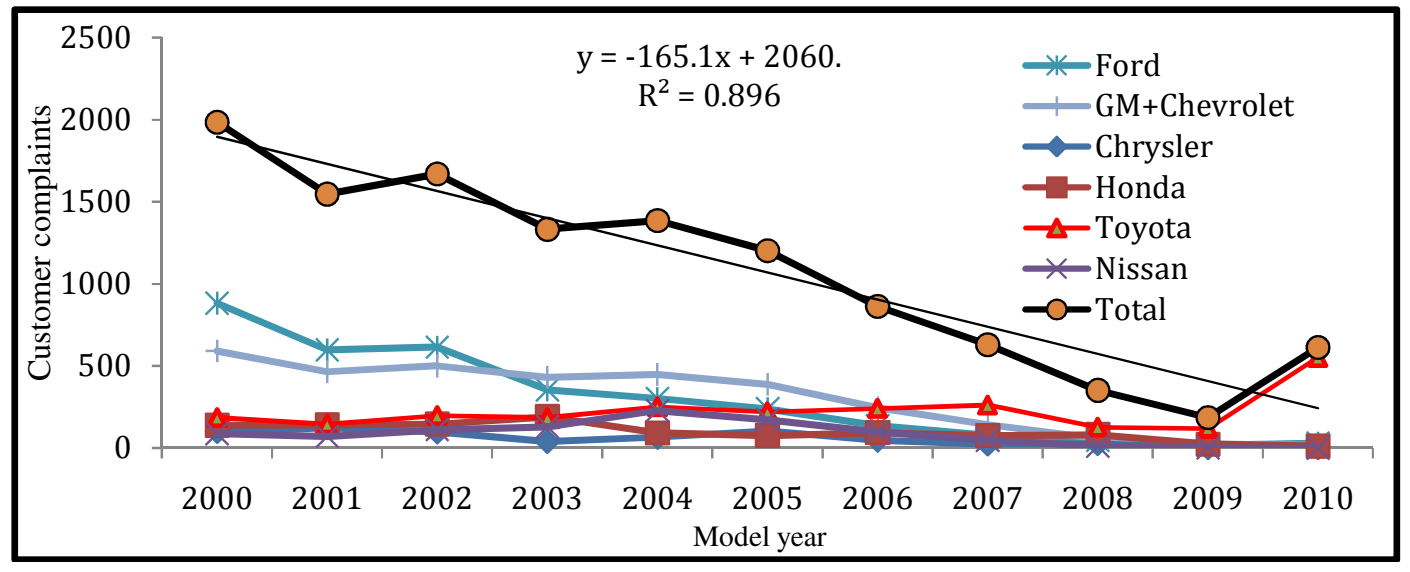

Figure 7: Relationship between car model year and customer complaints 


\section{CONCLUSION}

Analysis of car recall data shows that while every carmaker has experienced recalls, the majority of recalls are initiated by only a few carmakers. Recallsare a routine event in the car industry and the question arises whether the big carmakers really care about product quality and customer safety.

Historical car sales data for the last decade shows that in the US the most popular car makers initiatethe greatest number of recalls. These makers have conducted about $70 \%$ of total recalls during the last ten years; this implies the most popular carmakers have more recalls. US cars experience more recallscompared to Japanese cars. The current trend in comparative car recalls between Japan and the US is consistent with research conducted in the 90's by Barber and Darroug[16]. Even after more than a decade, in the US market Japanese car makers experience less recalls than their US counterparts; confirming Japanese superiority in terms of quality and reliability.

Genuine customer complaints are assumed to be a trigger for car recalls.From NHTSA data, it is identified that the six top car makers also experience more customer complaints. Among the top car makers, GM and Ford record the highest numbers of customer complaints, and Toyota is in third position. Among all cars, recent Toyota models have a higher number of customer complaints than rival makers. Though it seems some carmakers experience more complaints, differences in the average number of customer complaints among the top manufacturers is not statistically significant. Comparing customer complaints with recalls for different car makers, it shows recalls frequency and customer complaints are indeed correlated. This means many recalls are initiated by valid customer complaints and car makers shouldn't delay in addressing customer concerns [41].

Statistical analysis shows significant negative correlation between car model year and recalls frequency i.e. more recent car year models have less recalls compared to older models. It can be seen that most recalls occur during the first five years of the model year. Furthermore, analysis shows a strong negative correlation between recalls frequency and car recall time after the model year. This resarch finding can be useful for customers to deal with manufacturers in terms of after sales warranty and services during this peiord. It is interesting to observe that recently many car makers offer a five year warranty for new cars. Manufacturers can consider this to be a cooling off period, during which they should be ready for potential recalls. However, the best option would be to find root causes and avoid the mishap of car recalls.

Ideally the TQM philosophy calls for 'inspection at the source' to reduce duplicated efforts in the later process[41]. If we look at top car makers such as GM, Ford, and Toyota, thesecompanies have pioneered many quality principals and state-of-the art manufacturing techniques that lead to better quality. Among the success histories, Toyota is a forerunner for its production systems that incorporate TQM and Just in Time [40] system as a model for other to follow. However, revelations of Toyota's quality-control problems over the years were so concerning that many found it difficult to reconcile them with the firm's historic reputation for quality production methods [42]. According to Camuffo \& Weber [43], from 1995 onward, Toyota departed from the consistency and robustness of its fabled production basics and management principles (i.e., the Toyota Way) that had brought it an enviable global reputation for quality [42].Ford is a prime example in reflecting the quality approach of the U.S. automotive industry in the mid-80's, and adopted Six-Sigma the late-90's. GM was the market leader in the global auto-mobile industry for 77 consecutive years from 1931 through 2007and adopted many of the quality management philosophies such as TQM $[42,44]$. 
Unfortunately, car recalls occur due to design or manufacturing problems[2]. Some are accusing auto-makers 'faster times-to-market strategy' that pushes reduction of product development and testing lead times, and results in vehicles with more hidden faults in the market that are later recalled $[14,45]$.

Non-fulfillment of product quality is an external cost of quality for carmakers. Ultimate costs to customers may lead to death or physical disability[4]. For the manufacturer, costs are quite substantial.The cost function can be the cost of recall operations, cost of product replacement or repair, cost of losing market share or goodwill, cost of marketing the brand value, cost of lawsuit settlements, and cost of closing share price [11, 12, 46, 47]. Costs of product recall through the reverse distribution channel are at least two or three times higher than costs incurred in forward distribution, often due to small quantities of shipments, fluctuating and uncertain demand, and the urgency involved in the recall process $[9,10]$.

One important issue of recall is traceability of recalled product, product user, or product location in the supply chain. Proper identification of manufacturing fault of recall can help manufacturers to stop the production line of that particular product instead of pursuing massive recalls of entire batch of product. Sometimes tracing the product fault within the international supply chain network is difficult because of the complexity of the chain [41].

Overall, this research identifies some interesting issues of recalls and research findings will be beneficial for car makers, government authorities who deal with recalls, insurance companies, and researchers. This study opens up new research directions in the car recalls area. Car recall research can be further extended to quality assurance research, identification of the costing of the recalls process, and supply chain and logistics issues related to recalls. The research hasn't considered the impact of recalls on carmakers financial performance or goodwill. Further extension of the research can be done by including factors such as: the volume of car recalls, key causes of recall, and recall processes. Overall, this research provides insights of current car recalls and related issues.

\section{REFERENCES}

[1] K. Ahsan, "Understanding trends of car recalls," in IEEE International Conference on Industrial Engineering and Engineering Management (IEEM 2010), 2010, pp. 1123-1127.

[2] P. W. Beamish and H. Bapuji, "Toy Recalls and China: Emotion vs. Evidence," Management and Organization Review, vol. 4, pp. 197-209, 2008.

[3] M. A. Lyles, B. B. Flynn, and M. T. Frohlich, "All Supply Chains Don't Flow Through: Understanding Supply Chain Issues in Product Recalls," Management and Organization Review, vol. 4, pp. 167-182, 2008.

[4] M. Hora, H. Bapuji, and A. V. Roth, "Safety hazard and time to recall: The role of recall strategy, product defect type, and supply chain player in the US toy industry," Journal of Operations Management, vol. 29, pp. 766-777, 2011.

[5] A. Marucheck, N. Greis, C. Mena, and L. Cai, "Product safety and security in the global supply chain: Issues, challenges and research opportunities," Journal of Operations Management, vol. 29, pp. 707-720, 2011.

[6] K. Ahsan, "Car Recalls: A Problem Unique to Toyota or For All Car Makers?," presented at the The 3rd International Conference on Industrial Engineering and Operations Management (IEOM 2012), Istanbul, Turkey, 2012.

[7] R. Moll, "Ford Motor Company and Firestone tyre recall," Journal of Public Affairs, vol. 3, pp. 200-211, 2003.

[8] R. M. Monczka and R. J. Trent, "Purchasing and sourcing strategy: trends and implications," Center for Advanced Purchasing Studies, Tempe, Arizona, 1995. 
[9] V. Jayaraman, R. A. Patterson, and E. Rolland, "The design of reverse distribution networks: models and solution procedures," European Journal of Operational Research, vol. 150, pp. 128149, 2003.

[10] R. Chandran and R. A. Lancioni, "Product Recall: A Challenge for the 1980s," International Journal of Physical Distribution \& Logistics Management, vol. 11, pp. 46-55, 1981.

[11] B. Berman, "Planning for the inevitable product recall," Business Horizons, vol. 42, pp. 69-78, 1999.

[12] F. Gomer, "Recalls...when Supply Chain Management turns into Crisis Management," Supply Chain Asia, pp. 24-26, 2008.

[13] A. Marucheck, N. Greis, C. Mena, and L. Cai, "Product safety and security in the global supply chain: Issues, challenges and research opportunities," Journal of Operations Management, vol. 29, pp. 707-720, 2011.

[14] H. Bates, M. Holweg, M. Lewis, and N. Oliver, "Motor vehicle recalls: Trends, patterns and emerging issues," Omega, vol. 35, pp. 202-210, 2007.

[15] N. G. Rupp, "The Attributes of a Costly Recall: Evidence from the Automovtive Industry," Review of Industrail Organization, vol. 25, pp. 21-44, 2004.

[16] B. M. Barber and M. N. Darrough, "Product reliability and firm value: the experience of American and Japanese automakers, 1973-1992," Journal of Political Economy, vol. 104, pp. 1084-1099, 1996.

[17] M. W. Nichols and G. M. Fournier, "Recovering from a bad reputation: changing beliefs about the quality of US autos," International Journal of Industrial Organization, vol. 17, pp. 299-318, 1999.

[18] N. G. Rupp and C. R. Taylor, "Who initiates recalls and who cares? Evidence from the automotive industry," Journal of Industrial Economics, vol. 1, pp. 123-149, 2002.

[19] NHTSA. (2010, May 2010). Search for Recalls. Available: http://wwwodi.nhtsa.dot.gov/cars/problems/recalls/results.cfm

[20] ARFC. (2010). Automotive Recalls for Consumers Available: http://www.arfc.org/autos/toyota/recalls.aspx

[21] Y. K. Bae and H. Benítez Silva, "Do vehicle recalls reduce the number of accidents? The case of the US car market," Journal of Policy Analysis and Management, vol. 30, pp. 821-862, 2011.

[22] S. Kumar and E. M. Budin, "Prevention and management of product recalls in the processed food industry: a case study based on an exporter's perspective," Technovation, vol. 26, pp. 739-750, 2006.

[23] Y. Chen, S. Ganesan, and Y. Liu, "Does a firm's product-recall strategy affect its financial value? An examination of strategic alternatives during product-harm crises," Journal of Marketing, vol. 73, pp. 214-226, 2009.

[24] M. R. Thomsen and A. M. McKenzie, "Market incentives for safe foods: an examination of shareholder losses from meat and poultry recalls," American Journal of Agricultural Economics, pp. 526-538, 2001.

[25] V. Salin and N. H. Hooker, "Stock market reaction to food recalls," Review of Agricultural Economics, vol. 23, p. 33, 2001.

[26] M. Rhee and P. R. Haunschild, "The liability of good reputation: A study of product recalls in the US automobile industry," Organization Science, vol. 17, p. 101, 2006.

[27] P. R. Haunschild and M. Rhee, "The role of volition in Organizational Learning: the case of Automovitve Product Recalls," Management Science, vol. 50, pp. 1545-1560, 2004.

[28] Y. Choi and Y.-H. Lin, "Consumer responses to Mattel product recalls posted on online bulletin boards: Exploring two types of emotion," Journal of Public Relations Research, vol. 21, pp. 198207, 2009.

[29] G. Jarrell and S. Peltzman, "The impact of product recalls on the wealth of sellers," The Journal of Political Economy, vol. 93, pp. 512-536, 1985.

[30] L. Eagle, J. Hawkins, P. J. Kitchen, and L. C. Rose, "Brand sickness and health following major product withdrawals," Journal of Product \& Brand Management, vol. 14, pp. 310-321, 2005.

[31] K. K. Boyer and M. L. Swink, "Empirical elephants-why multiple methods are essential to quality research in operations and supply chain management," Journal of Operations Management, vol. 26, pp. 338-344, 2008.

[32] A. V. Roth, "Applications of empirical science in manufacturing and service operations," Manufacturing \& Service Operations Management, vol. 9, pp. 353-367, 2007. 
[33] V. Singhal, B. B. Flynn, P. T. Ward, A. V. Roth, and V. Gaur, "Editorial: Empirical elephantsWhy multiple methods are essential to quality research in operations and supply chain management," Journal of Operations Management, vol. 26, pp. 345-348, 2008.

[34] M. Fisher, "Strengthening the empirical base of operations management," Manufacturing \& Service Operations Management, vol. 9, pp. 368-382, 2007.

[35] R. Calantone and S. K. Vickery, "Special topic forum on using archival and secondary data sources in supply chain management research," Journal of Supply Chain Management, vol. 45, pp. 94-95, 2009.

[36] myCarsStats. (2010, May 2010). Car Recall Scoreboards and Car Reports Listed by Car Make. Available: http://www.mycarstats.com/reports/recalls.aspx

[37] Reuters. (2010, June 2010). Available: http://www.reuters.com/assets

[38] W. s. AutoInfoBank. (2010, May 2010). Key Automotive Data. Available: http://wardsauto.com/keydata/

[39] Toyota. (2010, June 2010). Toyota USA Newsroom. Available: http://pressroom.toyota.com

[40] T. Foscht, K. Ernstreiter, C. M. Iii, I. Sinha, and B. Swoboda, "Retaining or returning?: Some insights for a better understanding of return behaviour," International Journal of Retail \& Distribution Management, vol. 41, pp. 113-134, 2013.

[41] C. S. Tang, "Making products safe: process and challenges," International Commerce Review, vol. 8, pp. 48-55, 2008.

[42] S. D. Chowdhury, "Strategic roads that diverge or converge: GM and Toyota in the battle for the top," Business Horizons, 2013.

[43] A. Camuffo and D. R. Weber, "The Toyota Way and the Crisis: A New Industrial Divide?," Sustaining Industrial Competitiveness After the Crisis: Lessons from the Automotive Industry, p. 57, 2012.

[44] C. C. Pegels, "Total quality management defined in terms of reported practice," International Journal of Quality \& Reliability Management, vol. 11, pp. 6-18, 1994.

[45] T. Fujimoto, "Shortening lead time through early problem-solving-a new round of capabilitybuilding competition in the auto industry," New Product Development and Production Networks, Berlin, Springer, pp. 23-54, 2000.

[46] L. R. Khan and R. A. Sarker, "An optimal batch size for a JIT manufacturing system," Computers \& Industrial Engineering, vol. 42, pp. 127-136, 2002.

[47] A. Jamal, B. R. Sarker, and S. Mondal, "Optimal manufacturing batch size with rework process at a single-stage production system," Computers \& Industrial Engineering, vol. 47, pp. 77-89, 2004.

\section{Author}

Kamrul Ahsan, $\mathrm{PhD}$, is a senior lecturer in the Supply Chain and Logistics Discipline, College of Business, Victoria University, Australia. His publications have appeared in peer-reviewed journals, such as the International Journal of Project Management, International Transactions inOperational Research,Asia Pacific Journal of Operational Research, Journal of HealthManagement, International Journal of Operations and Quantitative Management, and others. He also received the Project Management Institution New Zealand (PMINZ) research achievement award in 2011. His co-authored article on remanufacturing was selected for the best paper award at the 21st International Conference on Production Research (ICPR 21), 2011 in Stuttgart, Germany. He is a member of Project Management Institute (PMI) and a Charter Member of the Chartered Institute of Logistics and Transport Australia (CILTA). 